\title{
THE EFFECT OF THE MOTIVATION OF AVOIDING RIBA AND KNOWLEDGE OF SHARIA BANKING PRODUCTS ON THE DECISION TO BECOME A CUSTOMER AT PT. BANK MUAMALAT INDONESIA TBK KC PADANGSIDIMPUAN
}

\author{
Heni $^{1}$, Windari ${ }^{2}$, Ali Hardana ${ }^{3}$, Syuaib Nasution ${ }^{4}$ \\ ${ }^{1}$ IAIN Padangsidimpuan (Perbankan Syariah, FEBI, IAIN Padangsidimpuan) \\ ${ }^{2}$ IAIN Padangsidimpuan (Ekonomi Syariah, FEBI, IAIN Padangsidimpuan) \\ ${ }^{3}$ IAIN Padangsidimpuan (Ekonomi Syariah, FEBI, IAIN Padangsidimpuan) \\ ${ }^{4}$ IAIN Padangsidimpuan (Perbankan Syariah, FEBI, IAIN Padangsidimpuan) \\ heni@gmail.com ${ }^{1}$, wwindariok@gmail.com² ${ }^{2}$ alihardana@iain-padangsidimpuan.ac.id ${ }^{3}$, \\ syuaibnasution@iain-padangsidimpuan.ac.id ${ }^{4}$
}

\begin{abstract}
ABSTRAK
Penelitian ini bertujuan untuk mengetahui pengaruh yang signifikan antara motivasi menghindari riba dan pengatahuan produk perbankan syariah terhadap keputusan menjadi nasabah di PT. Bank Muamalat Indonesia Tbk KC Padangsidimpuan. Metode yang digunakan dalam penelitian ini adalah kuantitatif deskriptif. Teknik pengumpulan data yang digunakan adalah kuesioner dan dokumentasi. Pengambilan sampel dalam penelitian ini menggunakan random sampling dengan jumlah sampel 99 orang. Untuk mempermudah proses analisis data penelitian ini maka dibantu dengan program SPSS versi 23. Hasil uji t menunjukkan bahwa terdapat pengaruh yang signifikan antara motivasi menghindari riba dan pengetahuan produk perbankan syariah terhadap keputusan menjadi nasabah. Berdasarkan hasil ini menunjukan bahwa pengaruh variabel motivasi menghindari riba dan pengetahuan produk perbankan syariah terhadap variabel keputusan menjadi nasabah.
\end{abstract}

Kata Kunci: Motivasi Menghindari Riba, Pengetahuan Produk Perbankan Syariah, Keputusan Menjadi Nasabah

\begin{abstract}
This study aims to determine the significant influence between motivation to avoid usury and knowledge of Islamic banking products on the decision to become a customer at PT. Bank Muamalat Indonesia Tbk KC Padangsidimpuan. The method used in this research is descriptive quantitative. The data collection techniques used were questionnaires and documentation. Sampling in this study using random sampling with a sample size of 99 people. To simplify the data analysis process, this research was assisted by the SPSS version 23 program. The $t$ test results indicate that there is a significant influence between motivation to avoid usury and knowledge of Islamic banking products on the decision to become a customer. Based this shows that the influence of the motivation variable to avoid usury and knowledge of Islamic banking products on the customer satisfaction variable.

Keywords: Motivation to Avoid Riba, Knowledge of Islamic Banking Products, Decision to Become a Customer
\end{abstract}




\section{A. PENDAHULUAN}

Secara umum, bank adalah lembaga yang melaksanakan tiga fungsi utama yaitu menghimpun dana, menyalurkan dana, melayani jasa keuangan lainnya, yag merupakan fungsi utama dari bank konvensional. Namun bank syariah memiliki empat fungsi dalam kegiatan operasionalnya. Selain dari ketiga fungsi utama diatas, satu fungsi utama lainnya yang ada pada bank syariah adalah fungsi sosial dalam bentuk kegiatan menghimpun dan penyaluran dana zakat, infak, dan sedekah serta menyalurkan dana dalam bentuk pinjaman kebajikan (qardul hasan). Antono dan Perwataatmadja membedakan menjadi dua pengertian, Bank Islam adalah bank yang beroperasi dengan prinsip syariah Islam dan bank yang tata cara beroperasinya mengacu kepada ketentuan-ketentuan Al-Qur'an dan Hadits.

Dunia perbankan di Indonesia, yang berlandaskan syariah muncul sebagai dinamika perkembangan bank konvensional. Di Indonesia hadir sebagai gebrakan awal, yaitu Bank Muamalat Indonesia bank yang berladaskan syariah. Memang di Indonesia landasan hukum syariah masih lemah. Hal tersebut jelas terpapar dalam UU No. 7 Tahun 1992, tetapi bukan sebagai halangan perkembangan bank syariah, namun tetap merupakan tonggak penting bagi keberadaan bank syariah di Indonesia. Bahkan bukan hanya itu saja, disitu tertulis bahwa bank konvensional membuka unit yang berbasis syariah. Sejak saat itu mulailah bermunculan bank konvensional yang membuka unit-unit bank syariah.

Ada alasan utama berdirinya perbankan syariah di Indonesia yaitu adanya pandangan bahwa bunga pada bank konvensional hukumnya haram dan dari segi ekonomi dimana penyerahan risiko dibebankan pada salah satu pihak dinilai melanggar norma keadilan. Penilaian tersebut diperkuat dengan munculnya fatwa yang dikeluarkan Majelis Ulama Indonesia (MUI) yang menyatakan bahwa bunga bank sama dengan riba dan hukumnya haram dalam syariah Islam. Oleh karena itu, bank syariah hadir di Indonesia sebagai alternatif terhadap persoalan pertentangan antara bunga bank dan riba. Riba berarti menetapkan bunga atau melebihkan jumlah pinjaman pokok secara bathil, dan menurut jumhur ulama riba hukumnya haram.

Pengembangan suatu produk sangat didasari oleh kepercayaan para konsumen (nasabah) bila mana dalam pembayaran cicilan angsuran meningkat tajam, hal ini secara tidak langsung rasa ketakutan konsumen telah menghantui pada besarnya angsuran yang dibayarkan perbulan. Konsumen atau nasabah akan memperhatikan kualitas dari suatu perbankan seperti pelayanan serta produk yang ditawarkan sehingga nasabah termotivasi untuk menggunakannya dengan mempertimbangkan hal itu untuk mencari kepuasan. Adapun faktorfaktor yang mempengaruhi pengambilan keputusan nasabah dalam memilih produk 
perbankan syariah adalah process, brand awareness dan perceived quality, physical evidence, perceived value dan faktor social, pricing, promotion, people dan faktor sosial, produk dan faktor pribadi, pleace, physical evidence dan faktor budaya, dan yang paling dominan berpengaruh adalah process.

Pengetahuan produk mencakup kesadaran akan kategori dan jenis produk, terminologi produk, atribut atau ciri produk, dan kepercayaan tentang jenis produk secara umum. Informasi ini diperoleh melalui analisis kesadaran konsumen dan jenis produk yang tersedia. Salah satu aspek pengetahuan produk adalah harga, sesuatu yang dapat digunakan untuk mendapatkan informasi baru dan membuat pilihan. Pengetahuan produk akan menimbulkan motivasi nasabah untuk melakukan pembelian sebuah produk sehingga dapat meningkatkan jumlah nasabah setiap tahunnya seperti di PT. Bank Muamalat Indonesia Tbk, Kc Padangsidimpuan setiap tahunnya jumlah nasabah selalu bertambah.

Berikut adalah perkembangan jumlah nasabah pada produk-produk di PT. Bank Muamalat Indonesia Tbk, KC Padangsidimpuan dari tahun 2014-2018:

Tabel I.1

Data Jumlah Nasabah PT. Bank

Muamalat Indonesia Tbk, KC Padangsidimpuan dari Tahun 2014-2018:

\begin{tabular}{|c|c|c|c|c|c|c|c|}
\hline No & Tahun & $\begin{array}{c}\text { Tabun } \\
\text { gan }\end{array}$ & $\%$ & $\begin{array}{c}\text { Depos } \\
\text { ito }\end{array}$ & $\%$ & $\begin{array}{c}\text { Gir } \\
\text { o }\end{array}$ & $\%$ \\
\hline 1 & 2014 & 5.798 & 97,3 & 15 & 0,25 & 143 & $\begin{array}{c}2,4 \\
0\end{array}$ \\
\hline 2 & 2015 & 6.274 & 97,4 & 18 & 0,27 & 145 & $\begin{array}{c}2,2 \\
5\end{array}$ \\
\hline 3 & 2016 & 7.024 & 97,6 & 27 & 0,37 & 145 & $\begin{array}{c}2,0 \\
1\end{array}$ \\
\hline 4 & 2017 & 7.706 & 97,6 & 41 & 0,51 & 147 & 1,8 \\
\hline
\end{tabular}

POINT Vol. 1, No. 2, Des 2020

\begin{tabular}{|c|c|c|c|c|c|c|c|}
\hline & & & & & & & 6 \\
\hline 5 & 2018 & 8.948 & 97,5 & 79 & 0,86 & 149 & $\begin{array}{c}1,6 \\
2\end{array}$ \\
\hline
\end{tabular}

Sumber: PT. Bank Muamalat Indonesia Tbk, KC Padangsidimpuan

Berdasarkan tabel tersebut perkembangan jumlah nasabah meningkat tiap tahunnya dikarenakan pada masa sekarang ini sudah banyak masyarakat yang mengetahui tentang produk-produk perbankan syariah pada PT. Bank Muamalat Indonesia Tbk, KC Padangsidimpuan yang tentunya baik pihak nasabah atau bank tidak ada yang merasa terdzolimi karena hubungan nasabah dengan bank adalah mitra.

Berdasarkan uraian di atas maka penulis tertarik untuk melakukan penelitian dengan judul "Pengaruh Motivasi Menghindari Riba dan Pengetahuan Produk Perbankan Syariah Terhadap Keputusan Menjadi Nasabah di PT. Bank Muamalat Indonesia Tbk, KC Padangsidimpuan".

\section{B. METODE}

Lokasi penelitian adalah PT. Bank Muamalat Indonesia Tbk, KC Padangsidimpuan. Penelitian ini mulai dilaksanakan pada bulan Oktober 2019 sampai Juni 2020.

Metode yang digunakan dalam penelitian ini adalah deskriptif kuantitatif yaitu penelitian yang menggambarkan atau menguraikan suatu keadaan atau kejadian sejelas mungkin dengan cara menggunakan kuesioner sebagai alat untuk mengumpulkan keterangan dan informasi yang diolah dengan 
menggunakan statistik, yaitu analisis regresi linier berganda untuk mengetahui hubungan secara linear antara dua atau lebih variabel independen dengan variabel dependen. Penelitian kuantitatif adalah penelitian yang menggunakan pengukuran dengan angka dan dianaliasa dengan menggunakan statistik.

Populasi dalam penelitian ini adalah nasabah di PT. Bank Muamalat Indonesia Tbk, KC Padangsidimpuan dengan total 9.176 nasabah. Penentuan sampel pada penelitian ini menggunakan rumus slovin yaitu:

$$
n=\frac{N}{1+\mathrm{Ne} 2}
$$

Dimana:

$$
\begin{aligned}
& \text { n :jumlah sampel } \\
& \mathrm{N} \quad \text { :jumlah populasi } \\
& \text { e } \quad \text { :presisi (persen kelonggaran } \\
& \text { ketidak telitian/batas } \\
& \text { kesalahan) penarikan sampel } \\
& 10 \%=0,1 \\
& \mathrm{n}=\quad 9.176 \\
& 1+9.176(0,1) 2 \\
& =9.176 \\
& 1+91,79 \\
& =9.176 \\
& 92,76 \\
& =\quad 98,92
\end{aligned}
$$

Karena nilai $\mathrm{n}=98,92$ tidak mungkin diambil sampel sebanyak 98,92 sehingga harus digenapkan menjadi 99 orang. Oleh karena itu, jumlah sampel pada penelitian ini ialah

\begin{tabular}{|c|c|c|c|}
\hline $\begin{array}{c}\text { Item } \\
\text { Pernyataan }\end{array}$ & $r_{\text {hitung }}$ & $r_{\text {tabel }}$ & Keterangan \\
\hline 1 & 0,505 & \multirow{6}{*}{$\begin{array}{c}\text { Instrumen } \\
\text { valid jika } \\
r_{\text {hitung }}> \\
r_{\text {tabel }} \\
\text { dengan df } \\
=n-2= \\
99-2=97 \\
\text { pada taraf } \\
\text { signifikan } \\
5 \% \\
\text { sehingga } \\
\text { diperoleh } \\
r_{\text {tabel }}= \\
0,1663\end{array}$} & Valid \\
\hline 2 & 0,614 & & Valid \\
\hline 3 & 0,504 & & Valid \\
\hline 4 & 0,652 & & Valid \\
\hline 5 & 0,590 & & Valid \\
\hline 6 & 0,617 & & Valid \\
\hline
\end{tabular}
sebanyak 99 orang.
Teknis analisis data yang digunakan dalam penelitian ini terdiri dari uji instrumen (uji validitas dan uji reliabilitas), uji asumsi klasik (uji normalitas data, uji multikolinearitas dan uji heteroskedastisitas), analisis regresi linier berganda, koefisien determinasi $\left(R^{2}\right)$, uji hipotesis (uji koefisian regresi parsial atau uji t dan uji koefisien regresi secara bersama-sama atau uji F)

\section{HASIL DAN PEMBAHASAN}

1. Uji Validitas

Tabel IV.1 Hasil Uji Validitas Variabel Motivasi Menghindari Riba (X1)

Sumber: Data penelitian diolah, 2020.

Hasil uji validitas berdasarkan tabel di atas dapat diketahui bahwa dari seluruh item pernyataan semuanya valid.

Tabel IV.2

Hasil Uji Validitas Variabel Pengetahuan Produk Perbankan Syariah (X2)

\begin{tabular}{|c|c|c|c|}
\hline $\begin{array}{c}\text { Item } \\
\text { Pernyataan }\end{array}$ & $r_{\text {hitung }}$ & $r_{\text {tabel }}$ & Keterangan \\
\cline { 1 - 1 } & & & \\
\hline 2 & 0,631 & Instrumen & Valid \\
\hline 3 & 0,635 & valid jika & Valid \\
\hline 4 & 0,680 & $r_{\text {hitung }}>r_{\text {tabel }}$ & Valid \\
\cline { 1 - 2 } dengan df & 0,688 & Valid \\
\hline
\end{tabular}




\begin{tabular}{|c|c|c|c|}
\hline 5 & 0,700 & $=$ n-2 = 99- & Valid \\
\cline { 1 - 1 } & 0,658 & $2=97$ pada & Valid \\
& & taraf & \\
& & signifikan & \\
& & $5 \%$ & \\
& & sehingga & \\
& & diperoleh & \\
& & $r_{\text {tabel }}=$ & \\
& & 0,1663 & \\
\hline
\end{tabular}

Sumber: Data penelitian diolah, 2020.

Hasil uji validitas berdasarkan tabel di atas bahwa dari seluruh item pernyataan semuanya dinyatakan valid.

Tabel IV. 3

Hasil Uji Validitas Variabel Keputusan Menjadi Nasabah (Y)

\begin{tabular}{|c|c|c|c|}
\hline $\begin{array}{c}\text { Item } \\
\text { Pernyataan }\end{array}$ & $r_{\text {hitung }}$ & $r_{\text {tabel }}$ & Keterangan \\
\hline 1 & 0,426 & \multirow{10}{*}{$\begin{array}{c}\text { Instrumen } \\
\text { valid jika } \\
r_{\text {hitung }}>r_{\text {tabel }} \\
\text { dengan df = } \\
\mathrm{n}-2=99-2= \\
97 \text { pada taraf } \\
\text { signifikan 5\% } \\
\text { sehingga } \\
\text { diperoleh } \\
r_{\text {tabel }}=0,1663\end{array}$} & Valid \\
\hline 2 & 0,463 & & Valid \\
\hline 3 & 0,632 & & Valid \\
\hline 4 & 0,628 & & Valid \\
\hline 5 & 0,604 & & Valid \\
\hline 6 & 0,635 & & Valid \\
\hline 7 & 0,587 & & Valid \\
\hline 8 & 0,536 & & Valid \\
\hline 9 & 0,668 & & Valid \\
\hline 10 & 0,518 & & Valid \\
\hline
\end{tabular}

Sumber: Data penelitian diolah, 2020.

Hasil uji validitas berdasarkan tabel di atas bahwa dari seluruh item pernyataan semuanya dinyatakan valid.

2. Uji Realiabilitas

Tabel IV.4

Hasil Uji Reliabilitas

Reliability Statistics

\begin{tabular}{|c|c|c|}
\hline Variabel & Cronbach's Alpha & N of Item \\
\hline Motivasi \\
$\begin{array}{c}\text { Menghindari } \\
\text { Riba (X1) }\end{array}$ & .735 & 7 \\
\hline $\begin{array}{c}\text { Pengetahuan } \\
\text { Produk }\end{array}$ & .762 & 7 \\
$\begin{array}{c}\text { Perbankan } \\
\text { Syariah (X2) }\end{array}$ & & \\
\hline
\end{tabular}

POINT Vol. 1, No. 2, Des 2020

\begin{tabular}{|c|c|c|}
\hline $\begin{array}{c}\text { Keputusan } \\
\text { Menjadi }\end{array}$ & .737 & 11 \\
Nasabah $(\mathrm{Y})$ & & \\
\hline
\end{tabular}

Sumber: Data penelitian diolah, 2020.

Hasil uji realibilitas di atas pada motivasi menghindari riba diperoleh nilai cronbach's alpha 0,735 . Nilai cronbach's alpha 0,735 >0,6 sehingga variabel motivasi menghindari riba dinyatakan reliabel dan dapat diterima. Hasil uji reliabitas pada variabel pengetahuan produk perbakan syariah diperoleh nilai cronbach's alpha 0,762. Nilai cronbach's alpha 0,762 >0,6 sehingga variabel pengetahuan perbankan syariah dinyatakan reliabel dan dapat dieterima. Hasil uji reabilitas pada variabel keputusan menjadi nasabah diperoleh nilai cronbach's alpha 0,737. Nilai cronbach's alpha 0,737 $>0,6$ sehinggan variabel keputusan menjadi nasabah dinyatakan reliabel dan dapat diterima.

3. Uji Multikolinearitas

Tabel IV.6

Hasil Uji Multikolinearitas

\begin{tabular}{|c|c|c|c|c|c|c|c|}
\hline \multirow[b]{2}{*}{ Model } & \multicolumn{2}{|c|}{$\begin{array}{l}\text { Unstandardize } \\
\text { d Coefficients }\end{array}$} & \multirow[t]{2}{*}{$\begin{array}{c}\text { Stand } \\
\text { ardiz } \\
\text { ed } \\
\text { Coeff } \\
\text { icient } \\
\text { s } \\
\end{array}$} & \multirow[t]{2}{*}{$\mathrm{t}$} & \multirow[t]{2}{*}{ Sig. } & \multicolumn{2}{|c|}{$\begin{array}{c}\text { Collinearity } \\
\text { Statistics }\end{array}$} \\
\hline & B & $\begin{array}{l}\text { Std. } \\
\text { Error }\end{array}$ & & & & $\begin{array}{l}\text { Toler } \\
\text { ance }\end{array}$ & VIF \\
\hline (Constant) & $\begin{array}{r}11.35 \\
8\end{array}$ & 4.786 & & $\begin{array}{r}2.3 \\
73\end{array}$ & $\begin{array}{r}.02 \\
0\end{array}$ & & \\
\hline $\begin{array}{l}\text { Motivasi } \\
\text { menghind } \\
\text { ari riba }\end{array}$ & .531 & .192 & .262 & $\begin{array}{r}2.7 \\
70\end{array}$ & $\begin{array}{r}.00 \\
7\end{array}$ & .768 & 1.302 \\
\hline $\begin{array}{l}\text { Pengetahu } \\
\text { an produk } \\
\text { perbankan } \\
\text { syariah }\end{array}$ & .611 & .140 & .412 & $\begin{array}{r}4.3 \\
67\end{array}$ & $\begin{array}{r}.00 \\
0\end{array}$ & .768 & 1.302 \\
\hline
\end{tabular}

a. Dependent Variable: Keputusan Sumber: Data penelitian diolah, 2020.

Berdasarkan tabel di atas diketahui bahwa nilai VIF dari variabel motivasi 
menghindari riba sebesar $1,302<10$ dan variabel pengetahuan produk perbankan syariah sebasar 1,302 < 10. Maka dapat disimpulkan tidak terjadi multikolinearitas

\begin{tabular}{|c|c|c|c|c|c|}
\hline & & $\begin{array}{c}\text { motivasi } \\
\text { menghi } \\
\text { ndari } \\
\text { riba }\end{array}$ & $\begin{array}{l}\text { pengeta } \\
\text { huan } \\
\text { produk }\end{array}$ & $\begin{array}{l}\text { keputus } \\
\text { an } \\
\text { menjadi } \\
\text { nasabah }\end{array}$ & $\begin{array}{c}\text { Unstand } \\
\text { ardized } \\
\text { Residual }\end{array}$ \\
\hline \multirow{3}{*}{$\begin{array}{l}\text { motivasi } \\
\text { menghind } \\
\text { ari riba }\end{array}$} & $\begin{array}{l}\text { Pearson } \\
\text { Correlation }\end{array}$ & 1 & $.482 * *$ & $.460 * *$ & .000 \\
\hline & $\begin{array}{l}\text { Sig. (2- } \\
\text { tailed) }\end{array}$ & & .000 & .000 & 1.000 \\
\hline & $\mathrm{N}$ & 99 & 99 & 99 & 99 \\
\hline \multirow{3}{*}{$\begin{array}{l}\text { pengetah } \\
\text { uan } \\
\text { produk }\end{array}$} & $\begin{array}{l}\text { Pearson } \\
\text { Correlation }\end{array}$ & $.482^{* *}$ & 1 & $.538^{* *}$ & .000 \\
\hline & $\begin{array}{l}\text { Sig. (2- } \\
\text { tailed) }\end{array}$ & .000 & & .000 & 1.000 \\
\hline & $\mathrm{N}$ & 99 & 99 & 99 & 99 \\
\hline \multirow{3}{*}{$\begin{array}{l}\text { keputusa } \\
\text { n menjadi } \\
\text { nasabah }\end{array}$} & $\begin{array}{l}\text { Pearson } \\
\text { Correlation }\end{array}$ & $.460 * *$ & $.538 * *$ & 1 & $.811^{* *}$ \\
\hline & $\begin{array}{l}\text { Sig. (2- } \\
\text { tailed) }\end{array}$ & .000 & .000 & & .000 \\
\hline & $\mathrm{N}$ & 99 & 99 & 99 & 99 \\
\hline \multirow{3}{*}{$\begin{array}{l}\text { Unstandar } \\
\text { dized } \\
\text { Residual }\end{array}$} & $\begin{array}{l}\text { Pearson } \\
\text { Correlation }\end{array}$ & .000 & .000 & $.811^{* *}$ & 1 \\
\hline & $\begin{array}{l}\text { Sig. (2- } \\
\text { tailed) }\end{array}$ & 1.000 & 1.000 & .000 & \\
\hline & $\mathrm{N}$ & 99 & 99 & 99 & 99 \\
\hline
\end{tabular}

antara variabel independent. Sementara nilai tolerance dari motivasi menghindari riba sebasar 0,768 > 0,1 dan variabel pengatahuan produk perbankan syariah sebesar 0,768 > 0,1. Maka dapat disimpulkan bahwa nilai tolerance dari kedua variabel independent lebih besar dari 0,1 dari penelitian tersebut bahwa tidak terjadi multikolinearitas antara independent variable.

4. Uji Heteroskedastisitas

Tabel IV.7

Hasil Uji Heteroskedastisitas

\begin{tabular}{|c|c|c|c|c|c|}
\hline & & $\begin{array}{c}\text { motiv } \\
\text { asi } \\
\text { meng } \\
\text { hindar } \\
\text { i riba }\end{array}$ & $\begin{array}{l}\text { penget } \\
\text { ahuan } \\
\text { produk }\end{array}$ & $\begin{array}{c}\text { kepu } \\
\text { tusan } \\
\text { menj } \\
\text { adi } \\
\text { nasa } \\
\text { bah }\end{array}$ & $\begin{array}{c}\text { Unstan } \\
\text { dardize } \\
\text { d } \\
\text { Residu } \\
\text { al }\end{array}$ \\
\hline \multirow[t]{2}{*}{$\begin{array}{l}\text { motiva } \\
\text { si } \\
\text { mengh } \\
\text { indari } \\
\text { riba }\end{array}$} & $\begin{array}{l}\text { Pear } \\
\text { son } \\
\text { Corr } \\
\text { elati } \\
\text { on }\end{array}$ & 1 & $.482 * *$ & $\begin{array}{r}.460 * \\
*\end{array}$ & .000 \\
\hline & Sig. & & .000 & .000 & 1.000 \\
\hline
\end{tabular}

\begin{tabular}{|c|c|c|c|c|c|}
\hline & $\begin{array}{l}\text { (2- } \\
\text { taile } \\
\text { d) }\end{array}$ & & & & \\
\hline & $\mathrm{N}$ & 99 & 99 & 99 & 99 \\
\hline \multirow[t]{3}{*}{$\begin{array}{l}\text { penget } \\
\text { ahuan } \\
\text { produk }\end{array}$} & $\begin{array}{l}\text { Pear } \\
\text { son } \\
\text { Corr } \\
\text { elati } \\
\text { on }\end{array}$ & $\begin{array}{r}.482 * \\
*\end{array}$ & 1 & $\begin{array}{r}.538 * \\
*\end{array}$ & .000 \\
\hline & $\begin{array}{l}\text { Sig. } \\
\text { (2- } \\
\text { taile } \\
\text { d) }\end{array}$ & .000 & & .000 & 1.000 \\
\hline & $\mathrm{N}$ & 99 & 99 & 99 & 99 \\
\hline \multirow[t]{3}{*}{$\begin{array}{l}\text { keputu } \\
\text { san } \\
\text { menja } \\
\text { di } \\
\text { nasaba } \\
\text { h }\end{array}$} & $\begin{array}{l}\text { Pear } \\
\text { son } \\
\text { Corr } \\
\text { elati } \\
\text { on }\end{array}$ & $\begin{array}{r}.460 * \\
*\end{array}$ & $.538^{* *}$ & 1 & $.811^{* *}$ \\
\hline & $\begin{array}{l}\text { Sig. } \\
\text { (2- } \\
\text { taile } \\
\text { d) }\end{array}$ & .000 & .000 & & .000 \\
\hline & $\mathrm{N}$ & 99 & 99 & 99 & 99 \\
\hline \multirow[t]{3}{*}{$\begin{array}{l}\text { Unstan } \\
\text { dardize } \\
\text { d } \\
\text { Residu } \\
\text { al }\end{array}$} & $\begin{array}{l}\text { Pear } \\
\text { son } \\
\text { Corr } \\
\text { elati } \\
\text { on }\end{array}$ & .000 & .000 & $\begin{array}{r}.811^{*} \\
*\end{array}$ & 1 \\
\hline & $\begin{array}{l}\text { Sig. } \\
\text { (2- } \\
\text { taile } \\
\text { d) }\end{array}$ & 1.000 & 1.000 & .000 & \\
\hline & $\mathrm{N}$ & 99 & 99 & 99 & 99 \\
\hline
\end{tabular}

Sumber: Data penelitian diolah, 2020.

Berdasarkan tabel di atas hasil uji heteroskedastisitas dapat diketahui bahwa nilai signifikan dari variabel motivasi menghindari riba sebesar $1,000>0,10$ dan variabel pengetahuan produk perbakan syariah sebesar $1,000>0,10$. Jadi dari kedua variabel independent tersebut dapat dinyatakan tidak terjadi masalah heteroskedastisitas pada model regresi.

5. Uji Determinasi

Tabel IV.8

Hasil Uji Determinasi

Model Summaryb

\begin{tabular}{|l|c|c|c|c|}
\hline Model & $\mathrm{R}$ & $\begin{array}{c}\mathrm{R} \\
\text { Squar } \\
\mathrm{e}\end{array}$ & $\begin{array}{c}\text { Adjusted } \\
\text { R Square }\end{array}$ & $\begin{array}{c}\text { Std. } \\
\text { Error of } \\
\text { the } \\
\text { Estimate }\end{array}$ \\
\hline 1 & $.585 \mathrm{a}$ & .342 & .329 & 2.879 \\
\hline
\end{tabular}


a. Predictors: (Constant), pengetahuan produk, motivasi menghindari riba

b. Dependent Variable: keputusan menjadi nasabah

Sumber: Data penelitian diolah, 2020.

Berdasarkan hasil diatas diperoleh nilai $R^{2}$ ( $R$ Square) sebesar 0,342 atau 34,2\%. Hal ini menunjukkan bahwa prensentase pengeruh variabel motivasi menghindari riba dan pengetahuan produk perbankan syariah sebesar $34,2 \%$. Sedangkan sisanya sebesar $65,8 \%$ dipengaruhi oleh variabel lain yang tidak dimasukkan dalam model penelitian ini.

6. Uji Analisis Regresi Linear Berganda

Tabel IV.9

Analisis Regresi Linear Berganda

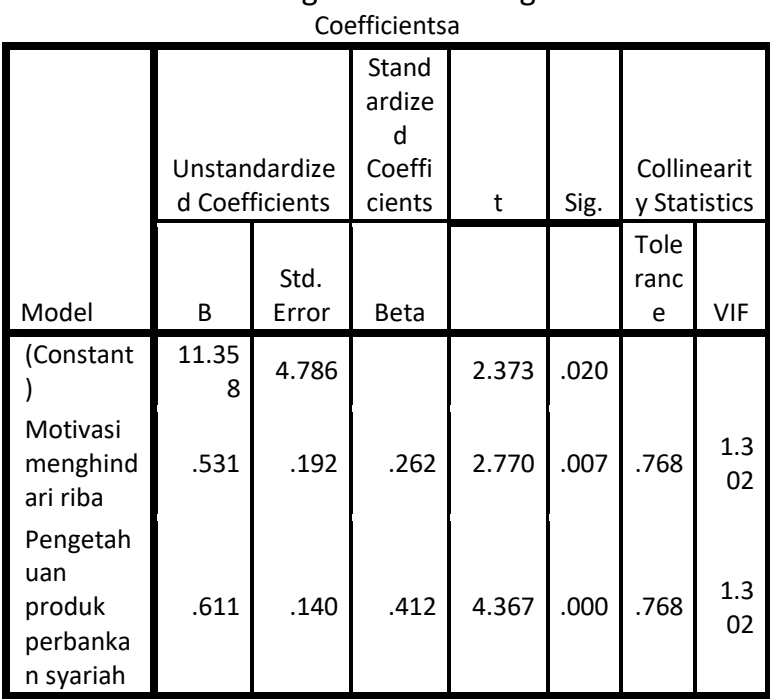

b. Dependent Variable: Keputusan

Sumber: Data penelitian diolah, 2020.

Keputusan $=\mathrm{a}+\mathrm{b} 1$ Motivasi $+\mathrm{b} 2$ Pengetahuan $+\mathrm{e}$

Keputusan $=11,358+0,531$ Motivasi $+0,611$ Pengetahuan $+\mathrm{e}$

Persamaan regresi tersebut dapat dijelaskan sebagai berikut:

a. Konstanta sebesar 11,358 artinya apabila variabel motivasi menghindari riba dan keputusan nasabah dianggap konstanta atau nilainya 0 , maka kinerja
POINT Vol. 1, No. 2, Des 2020 karyawan adalah keputusan menjadi nasabah adalah sebesar 11,358 satuan.

b. Koefisien regresi variabel motivasi menghindari riba sebesar 0,531 satuan. Apabila koefisien bernilai positif dinaikkan sebesar 1 satuan artinya terjadi hubungan positif antara motivasi menghindari riba dan keputusan menjadi nasabah, semakin tinggi motivasi menghindari riba maka semakin meningkat keputusan menjadi nasabah

c. Koefisien regresi variabel pengetahuan produk perbankan syariah sebesar 0,611 satuan. Apabila koefisien bernilai positif maka dinaikkan 1 satuan artinya terjadi hubungan positif antara pengetahuan produk perbankan syariah dengan dengan keputusan menjadi nasabah, semakin tinggi pengetahuan produk perbankan syariah maka semakin meningkat keputusan menjadi nasabah.

7. Uji Koefisien Secara Parsial (Uji t) Tabel IV.10

Uji Koefisien Secara Parsial (Uji t) Coefficientsa

\begin{tabular}{|c|c|c|c|c|c|c|c|}
\hline \multirow[b]{2}{*}{ Model } & \multicolumn{2}{|c|}{$\begin{array}{l}\text { Unstandardize } \\
\text { d Coefficients }\end{array}$} & \multirow[t]{2}{*}{$\begin{array}{c}\text { Stand } \\
\text { ardize } \\
\mathrm{d} \\
\text { Coeffi } \\
\text { cients }\end{array}$} & \multirow[t]{2}{*}{$\mathrm{T}$} & \multirow[t]{2}{*}{ Sig. } & \multicolumn{2}{|c|}{$\begin{array}{c}\text { Collinearity } \\
\text { Statistics }\end{array}$} \\
\hline & B & $\begin{array}{l}\text { Std. } \\
\text { Error }\end{array}$ & & & & $\begin{array}{c}\text { Tolera } \\
\text { nce }\end{array}$ & VIF \\
\hline (Constant) & $\begin{array}{r}11.35 \\
8\end{array}$ & 4.786 & & 2.373 & .020 & & \\
\hline $\begin{array}{l}\text { Motivasi } \\
\text { menghindari } \\
\text { riba }\end{array}$ & .531 & .192 & .262 & 2.770 & .007 & .768 & 1.302 \\
\hline
\end{tabular}


\begin{tabular}{|l|l|l|l|l|l|l|}
$\begin{array}{l}\text { Pengetahuan } \\
\text { produk } \\
\text { perbankan } \\
\text { syariah }\end{array}$ & .611 & .140 & .412 & 4.367 & .000 & .768 \\
\hline
\end{tabular}

c. Dependent Variable: Keputusan

Sumber: Data penelitian diolah, 2020.

Berdasarkan tabel di atas untuk ttabel diperoleh dari rumus $\mathrm{df}=\mathrm{n}-\mathrm{k}-1$ atau 99-2-1 $=96$ dengan menggunkan signifikan 10\%: $2=5 \%(0,05)$. Hasil yang diperoleh untuk ttabel sebesar 1,660 jika $t_{\text {hitung }}>t_{\text {tabel }}$ maka Ha diterima.

a. Berdasarkan tabel diatas dapat dilihat bahwa variabel motivasi menghindari riba sebesar 2,270>1,660 maka $\mathrm{HO}$ ditolak dan $\mathrm{Ha}$ diterima. Jadi dapat disimpulkan bahwa terdapat pengaruh antara motivasi menghindari riba terhadap keputusan menjadi nasabah di PT. Bank Muamalat Indonesia Tbk KC Padangsidimpuan secara parsial.

b. Pada variabel pengetahuan produk perbankan syariah sebasar 4,367 > 1,660 maka $\mathrm{HO}$ ditolak dan $\mathrm{Ha}$ diterima. Jadi dapat disimpulkan bahwa terdapat pengaruh antara pengetahuan produk perbankan syariah terhadap keputusan menjadi nasabah di PT. Bank Muamalat Indonesia Tbk KC Padangsidimpuan secara parsial.

8. Uji Koefisien Signifikan Simultan (Uji F)

Tabel IV.11

Hasil Uji Signifikan Simultan (Uji F)

\begin{tabular}{|c|c|c|c|c|c|}
\hline Model & $\begin{array}{l}\text { Sum of } \\
\text { Squares }\end{array}$ & Df & $\begin{array}{l}\text { Mean } \\
\text { Square }\end{array}$ & $\mathrm{F}$ & Sig. \\
\hline $\begin{array}{ll}1 & \text { Regressi } \\
\text { on }\end{array}$ & 414.362 & 2 & 207.181 & $\begin{array}{r}24.99 \\
9\end{array}$ & $.000 \mathrm{~b}$ \\
\hline Residual & 795.598 & 96 & 8.287 & & \\
\hline Total & 1209.960 & 98 & & & \\
\hline
\end{tabular}

a. Dependent Variable: keputusan menjadi nasabah

b. Predictors: (Constant), pengetahuan produk,

1.3 motivasi menghindari riba

Symber: Data penelitian diolah, 2020.

Berdasarkan hasil tabel di atas dapat diketahui nilai $F_{\text {hitung }}$ sebesar 24,999 dengan signifikan 0,05 dengan df 99-2-1 = 96. Hasil $F_{\text {tabel }}$ sebesar 3,09. Sehingga dapat disimpulkan bahwa $F_{\text {hitung }}>F_{\text {tabel }}(24,999>3,09)$ maka $\mathrm{HO}$ ditolak dan $\mathrm{Ha}$ diterima artinya terdapat pengaruh antara motivasi menghindari riba dan pengetahuan produk perbankan syariah secara bersama-sama (simultan) terhadap keputusan menjadi nasabah di PT. Bank Muamalat Indonesia Tbk KC Padangsidimpuan.

Setelah peneliti ini melakukan penelitian secara langsung dengan melakukan penyebaran angket yang ditujukan nasabah PT.

Bank Muamalat Indonesia Tbk KC Padangsidimpuan dan mengolah hasil dari jawaban para responden dari angket yang telah peneliti sebarkan melalui aplikasi SPSS 23 adalah sebagai berikut:

Berdasarkan hasil perhitungan R Square yaitu sebesar 0,342 atau (34,2\%). Hal ini menunjukkan bahwa variabel motivasi menghindari riba dan pengetahuan produk perbankan syariah terhadap variabel keputusan menjadi nasabah 34,2\% sedangkan sisanya sebesar $65,8 \%$ dipengaruhi oleh variabel lain yang belum diteliti dalam penelitian ini seperti pendapatan, lokasi, pelayanan, produk dan lain sebagainya.

a. Pengaruh Motivasi Menghindari Riba Terhadap Keputusan Menjadi Nasabah. 
Berdasarkan hasil penelitian dari hasil uji $\mathrm{t}$ bahwa thitung untuk variabel motivasi menghindari riba sebesar 2,770 dan untuk ttabel diperoleh dari rumus $d f=(n-k-1), d f=$ $(99-2-1)=96$ diperoleh sebesar 1,66088 yang artinya $t_{\text {hitung }}>t_{\text {tabel }}$ $(2,770>1.66088)$, begitupun dengan nilai signifikansi $0,007<0,05$ sehingga dapat disimpulkan bahwa pengaruh motivasi menghindari riba berpengaruh terhadap keputusan menjadi nasabah di PT. Bank Muamalat Indonesia Tbk KC Padangsidimpuan.

b. Pengaruh Pengetahuan Produk Perbankan Syariah Terhadap Keputusan Menjadi Nasabah.

Berdasarkan hasil uji t di atas nilai thitung untuk variabel pengetahuan produk perbankan syariah adalah 4,367 sedangkan nilai dari ttabel 1,66088 yang artinya $t_{\text {hitung }}$ $>t_{\text {tabel }}(4,367>1,66088)$. Begitupun dengan nilai signifikansi $0,000<0,05$. Jadi dapat disimpulkan bahwa pengetahuan produk perbankan syariah berpengaruh terhadap keputusan menjadi nasabah di PT. Bank Muamalat Indonesia Tbk KC Padangsidimpuan.

Penelitian ini didukung oleh hasil penelitian terdahulu yang dilakukan oleh Ida Nurlaeli yang
POINT Vol. 1, No. 2, Des 2020 berjudul Pengaruh Faktor Budaya, Psikologis, Pelayanan, Promosi dan Pengetahuan Tentang Produk Terhadap Keputusan Nasabah Memilih BPRS di Banyumas dengan menyatakan dalam penelitiannya bahwa variabel pengetuan tentang produk secara parsial berpengaruh positif terhadap kepusan menjadi nasabah.

c. Pengaruh Motivasi Menghindari Riba dan Pengetahuan Produk Perbankan Syariah Terhadap Keputusan Menjadi Nasabah.

Berdasarkan hasil uji signifikan simultan (Uji F) di atas dapat dijelaskan bahwa nilai fhitung sebesar 24,999 dan ftabel dapat dilihat pada tabel statistic dengan derajat kebebasan $\mathrm{df}=\mathrm{n}-\mathrm{k}-1$ atau 99-2-1 = 96 yang diperoleh nilainya sebesar 3,09 sehingga dapat disimpulkan bahwa $F_{\text {hitung }}>F_{\text {tabel }}(24,999>3,09)$ artinya hipotesis diterima. Hal ini berarti bahwa secara bersama-sama motivasi menghindari riba dan pengetahuan produk perbankan syariah mempunyai pengaruh yang signifikan terhadap keputusan menjadi nasabah di PT. Bank Muamalat Indonesia Tbk KC Padangsidimpuan.

\section{PENUTUP}

\section{Kesimpulan}

Berdasarkan hasil penelitian dan analisis data pada bab sebelumnya mengenai pengaruh motivasi "Menghindari Riba Dan 
Pengetahuan Produk Perbankan Syariah Terhadap Keputusan Menjadi Nasabah di PT. Bank Muamalat Indonesia Tbk KC Padangsidimpuan". Maka, kesimpulan dari penelitian adalah sebagai berikut:

a) Motivasi menghindari riba berpengaruh terhadap keputusan menjadi nasabah di PT. Bank Muamalat Indonesia Tbk KC Padangsidimpuan.

b) Pengetahuan produk perbankan syariah berpengaruh terhadap keputusan menjadi nasabah di PT. Bank Muamalat Indonesia Tbk KC Padangsidimpuan.

c) Motivasi menghindari riba dan pengetahuan produk perbankan syariah secara simultan (bersama-sama) berpengaruh terhadap keputusan menjadi nasabah di PT. Bank Muamalat Indonesia Tbk KC Padangsidimpuan.

\section{Saran}

Semoga adanya pengetahuan masyarakat terhadap minat produk perbankan syariah

\section{DAFTAR PUSTAKA}

Abdul Nasser Hasibuan, Asimetri Dalam Perbankan Syariah, At-Tijaroh, Volume 1, No. 1, Januari-Juni 2015.

Abdul Nasser Hasibuan, Jurnal Imara, "Strategi pemasaran produk funding di PT. Bank pembiayaan rakyat syariah padangsidimpuan", 2018.
Ali Hardana, Jurnal Al Masharif, "Model Pengembangan Kewirausahaan Di Perguruan Tinggi", 2018.

Adiwarman A. Karim, Bank Islam Analisis Fiqih dan Keuangan, Jakarta: PT Rajagrafindo Persada, 2011.

Anggita Novita Gampu, Dkk, "Analisis Motivasi, Persepsi, Dan Pengetahuan Terhadap Keputusan Nasabah Memilih Pt. Bank Sulutgo Cabang Utama Manado", Jurnal Emba, Vol.3 No.3 Sept. 2015, Hal.1330-1340.

Ela Patriana dan Nurismalatri, "Analisis Faktor Penentu Keputusan Konsumen Muslim Dalam Memilih Jasa Perbankan Bank Syariah Vc Bank Konvensional", Junal Lembaga Keuangan dan Perbankan, Vol 3,No. 1, Januari-Juni 2018.

Fatkhul Wahab, "Riba Transaksi Kotor Dalam Ekonomi", Jurnal Ekonomi Syariah (2017) Vol.02 No.02 : 26-41 ISSN 2503118X | elSSN 2580-4669.

Hendi Suhendi, Fiqh Muamalah, Jakarta: PT Raja Grafindo Persada, 2011.

Ismail, Perbankam Syariah, Jakarta: Kencana Prenada Media Group, 2013.

Nofinawati, "Perkembangan Perbankan Syariah di Indonesia", Juris Volume 14, Nomor 2 (Juli-Desember 2015).

Nugroho J. Setiadi, Perilaku Konsumen, Jakarta: Kencana Prenada Media Group, 2010.

Nur Aswani dan Masyuri, Metodologi Riset dan Manajemen Pemasaran, Malang: UIN Maliki Pers, 2011.

Tim Penyusun, Panduan Penulisan Skripsi, Padangsidmpuan: STAIN Padangsidimpuan, 2012.

Wawan Kurniawan, "Pengaruh Pengetahuan Konsumen, Kualitas Layanan Mengenai Lembaga Keuangan Syariah Terhadap Keputusan Menjadi Anggota Di Bmt An 
Heni ${ }^{1}$, Windari ${ }^{2}$, Ali Hardana ${ }^{3}$, Syuaib Nasution ${ }^{4}$

POINT Vol. 1, No. 2, Des 2020

Naafi Kabupaten Boyolali", (Skripsi: IAIN Surakarta, 2017).

Zulkifli Zainuddin, dkk, "Analisis Faktor Dalam

Pengambilan Keputusan Nasabah Memilih Produk Pembiayaan Perbankan Syariah", Jurnal Riset Manajemen dan Bisnis, Vol.1, No.1, Juni 2016: 1-12 ISSN 2527 - 7502 